\title{
Degradation of SARS-CoV-2 receptor ACE2 by the E3 ubiquitin ligase Skp2 in lung epithelial cells
}

\begin{abstract}
Guizhen Wang ${ }^{1,2}$, Qun Zhao ${ }^{1,3}$, Hui Zhang ${ }^{4}$, Fan Liang ${ }^{1,2}$, Chen Zhang ${ }^{1,2}$, Jun Wang ${ }^{5}$, Zhenyin Chen ${ }^{1,6}$, Ran Wu ${ }^{1,6}$, Hong Yu ${ }^{7}$, Beibei Sun ${ }^{1}$, Hua Guo ${ }^{1}$, Ruie Feng ${ }^{4}$, Kaifeng $\mathrm{Xu}^{5}$, Guangbiao Zhou $(\bowtie){ }^{1}$

${ }^{I}$ State Key Laboratory of Molecular Oncology, National Cancer Center/National Clinical Research Center for Cancer/Cancer Hospital, Chinese Academy of Medical Sciences and Peking Union Medical College, Beijing 100021, China; ${ }^{2}$ State Key Laboratory of Membrane Biology, Institute of Zoology, Chinese Academy of Sciences \& University of Chinese Academy of Sciences, Beijing 100101, China; ${ }^{3}$ Hubei University of Medicine, Shiyan 442000, China; ${ }^{4}$ Department of Pathology, Peking Union Medical College Hospital, Chinese Academy of Medical Sciences, Beijing 100730, China; ${ }^{5}$ Department of Pulmonary and Critical Care Medicine, Peking Union Medical College Hospital, Chinese Academy of Medical Sciences, Beijing 100730, China; ${ }^{6}$ Guizhou University School of Medicine, Guiyang 550025, China; ${ }^{7}$ School of Chinese Materia Medica, Beijing University of Chinese Medicine, Beijing 100029, China
\end{abstract}

(C) Higher Education Press 2021

\begin{abstract}
An unexpected observation among the COVID-19 pandemic is that smokers constituted only 1.4\% $18.5 \%$ of hospitalized adults, calling for an urgent investigation to determine the role of smoking in SARS-CoV-2 infection. Here, we show that cigarette smoke extract (CSE) and carcinogen benzo(a)pyrene (BaP) increase $A C E 2$ mRNA but trigger ACE2 protein catabolism. BaP induces an aryl hydrocarbon receptor (AhR)-dependent upregulation of the ubiquitin E3 ligase Skp2 for ACE2 ubiquitination. ACE2 in lung tissues of non-smokers is higher than in smokers, consistent with the findings that tobacco carcinogens downregulate ACE2 in mice. Tobacco carcinogens inhibit SARS-CoV-2 spike protein pseudovirions infection of the cells. Given that tobacco smoke accounts for 8 million deaths including 2.1 million cancer deaths annually and Skp2 is an oncoprotein, tobacco use should not be recommended and cessation plan should be prepared for smokers in COVID-19 pandemic.
\end{abstract}

Keywords SARS-CoV-2; tobacco smoke; benzo(a)pyrene; ACE2; Skp2

\section{Introduction}

Severe acute respiratory syndrome coronavirus 2 (SARSCoV-2), the pathogen of coronavirus disease 2019 (COVID-19), has infected 67516683 individuals and caused 1543027 deaths as of December 8, 2020 [1]. The association between tobacco smoking and COVID-19 incidence and severity remains controversial [2-8]. Observational studies [5-7] and meta-analyses [4,8] showed that among the confirmed COVID-19 cases, smoker patients constituted a relatively small proportion $(1.3 \%-14.5 \%)$ of the total cases. Active smoking is not associated with severity of COVID-19 [3], but is most likely associated with the negative progression and adverse outcomes of this disease [8]. Based on these findings,

Received November 25, 2020; accepted December 8, 2020

Correspondence: Guangbiao Zhou, gbzhou@cicams.ac.cn pharmaceutical nicotine administration is suggested to be a therapeutic/preventive approach for SARS-CoV-2 infection [7]. Meta-analysis conducted by World Health Organization (WHO) showed that smokers constituted $1.4 \%-18.5 \%$ of hospitalized adults, but smoking is associated with increased severity of the disease and death from COVID-19 [2]. Therefore, the effects of tobacco smoking on SARS-CoV-2 infection should be determined by an experimental study.

\section{Materials and methods}

\section{Patient samples}

The study was approved by the research ethics committees of the Chinese Academy of Medical Sciences Cancer Institute and Hospital. The lung biopsy samples of patients with benign diseases (Table S1) were obtained from Department of Pathology, Peking Union Medical College 
Hospital, and were analyzed by immunohistochemistry assay using an anti-ACE2 and anti-Skp2 antibodies. Fresh normal lung tissues, which were $5 \mathrm{~cm}$ away from tumor samples, were collected together with tumor tissues at surgical operation from 49 previously untreated patients with lung cancer (Table S2). The samples were lysed and tested by Western blot for the expression of ACE2 and Skp2.

\section{Animals}

The animal studies were approved by the Institutional Review Board of the Chinese Academy of Medical Sciences Cancer Institute and Hospital. All animal studies were conducted according to protocols approved by the Animal Ethics Committee of the Chinese Academy of Medical Sciences Cancer Institute and Hospital. A/J mice (5-6 weeks old) were purchased from the Jackson Laboratory (Bar Harbor, Maine, USA), and were bred and maintained in a specific pathogen-free environment. The mice were exposed to cigarette smoke [9] generated by DSI's Buxco Smoke Generator (Buxco, NC, USA) inside a perspex box, at a frequency of 8 cigarettes per day, 5 days per week for 3 weeks, or were treated with benzo(a)pyrene (Bap) at $100 \mathrm{mg} / \mathrm{kg}$ or nicotine-derived nitrosaminoketone (NNK) at $50 \mathrm{mg} / \mathrm{kg}$ twice a week for 5 weeks [10].

\section{Antibodies and reagents}

Antibodies used in this study included rabbit polyclonal anti-human ACE2 (\#ab15348, Abcam, Cambridge, MA, USA; 1:200 for immunofluorescence), rabbit monoclonal anti-human ACE2 (\#ab108252, Abcam; 1:1000 for Western blot), rabbit polyclonal anti-human ACE2 (\#4355, Cell Signaling Technology, Danvers, MA, USA; 1:1000 for Western blot), anti-TMPRSS2 (\#ab92323, Abcam; 1:1000 for Western blot), rabbit anti-Furin (\#ab183595, Abcam; 1:1000 for Western blot), rabbit anti-Skp2 (\#2652, Cell Signaling Technology; 1:1000 for Western blot), anti-GAPDH (\#5174, Cell Signaling Technology; 1:1000 for Western blot), and anti- $\beta$-Actin (\#A5441, Sigma, St. Louis, MO, USA; 1:5000 for Western blot). BaP (\#B1760) and NNK (\#78013) were purchased from Sigma. Cycloheximide (CHX), epoxomicin, MG132, chloroquine (CQ), phorbol 12-myristate 13-acetate (PMA), azilsartan, candesartan, olmesartan, and eprosartan were purchased from Selleck (Shanghai, China). Cigarette smoke extract (CSE) was prepared as previously described [11].

\section{Cell culture}

The cells were cultured in Dulbecco modified Eagle medium (DMEM) containing 10\% fetal bovine serum
(FBS; Gibco/BRL, Grand Island, NY, USA), $100 \mathrm{U} / \mathrm{mL}$ penicillin, $100 \mathrm{mg} / \mathrm{mL}$ streptomycin, and were treated with CSE, BaP, NNK, CHX, MG132, epoxomicin, and CQ as indicated [12-14]. The cells were transfected with $50 \mathrm{nmol} / \mathrm{L}$ double-stranded siRNA oligonucleotides (Table S3) using HiPerFect Transfection Reagent (Qiagen, Crawley, UK).

The total RNA was isolated using the TRIZOL Reagent (Invitrogen, Frederick, MD, USA) according to the manufacturer's instruction. Total RNA $(2 \mu \mathrm{g})$ was annealed with random primers at $65{ }^{\circ} \mathrm{C}$ for $5 \mathrm{~min}$. The cDNA was synthesized using a 1st-STRAND cDNA Synthesis Kit (Fermentas, Pittsburgh PA, USA). Quantitative RT-PCR was carried out using SYBR Premix ExTaq $^{\mathrm{TM}}$ (Takara Biotechnology, Dalian, China). The primers used in this study were listed in Table S3.

\section{Western blot}

Lung tissue samples and the cells were lysed on ice for $30 \mathrm{~min}$ in RIPA buffer $(50 \mathrm{mmol} / \mathrm{L}$ Tris- $\mathrm{HCl} \mathrm{pH} \mathrm{7.4,}$ $150 \mathrm{mmol} / \mathrm{L} \mathrm{NaCl}, 0.1 \%$ SDS, $1 \%$ deoxycholate, $1 \%$ Triton X-100, $1 \mathrm{mmol} / \mathrm{L}$ EDTA, $5 \mathrm{mmol} / \mathrm{L} \mathrm{NaF}, 1 \mathrm{mmol} / \mathrm{L}$ sodium vanadate, and protease inhibitors cocktail), quantitated, and subjected to $10 \%-15 \%$ SDS-PAGE, electrophoresed and transferred to a nitrocellulose membrane. After blocking with 5\% non-fat milk in Trisbuffered saline, the membrane was washed and incubated with indicated primary and secondary antibodies and detected by Luminescent Image Analyzer LSA 4000 (GE, Fairfield, CO, USA). Densitometry analyses of immunoblot bands were performed to quantitate the expression level of the proteins.

\section{Immunohistochemistry analysis}

The formalin-fixed, paraffin-embedded human or mouse lung specimens $(5 \mu \mathrm{m})$ were deparaffinized through xylene and graded alcohol, and subjected to a heat-induced epitope retrieval step in citrate buffer solution. The sections were then blocked with 5\% BSA for $30 \mathrm{~min}$ and incubated with indicated antibodies at $4{ }^{\circ} \mathrm{C}$ overnight, followed by incubation with secondary antibodies for $90 \mathrm{~min}$ at $37^{\circ} \mathrm{C}$. Detection was performed with 3,3'-diaminobenzidine (DAB, Zhongshan Golden Bridge Biotechnology Co., Ltd., Beijing, China) and counterstained with hematoxylin, dehydrated, cleared, and mounted using the routine processing. The immunoreactivity score was calculated as IRS $(0-12)=\mathrm{RP}(0-4) \times \mathrm{SI}(0-3)$, where RP is the percentage of staining-positive cells and SI is staining intensity.

\section{In vitro ubiqutination assay}

Ubiquitination assay was performed with Ubiquitylation 
Assay Kit (Abcam; \#ab139467) using recombinant carrier free ACE2 (\#933-ZN-010) and Skp1/Skp2 (\#E3-521-025) proteins bought from R\&D Systems (Minneapolis, MN, USA) or Flag-ACE2 and Flag-Skp1/Skp2 purified from $293 \mathrm{~T}$ cells. The proteins were incubated with $50 \mu \mathrm{L}$ reaction mixture (Boston Biochem), $2 \mathrm{mmol} / \mathrm{L} \mathrm{Mg}$-ATP (Abcam), $0.5 \mu \mathrm{g}$ E1 (Abcam), $2.5 \mu \mathrm{g} \mathrm{UbcH5a/UBE2D1}$ (Boston Biochem), and $2.5 \mu \mathrm{g}$ ubiquitin (Abcam) at $37^{\circ} \mathrm{C}$ for $2 \mathrm{~h}$. After incubation, the reaction was terminated with SDS loading buffer, and the ubiquitination was detected using Western blot assays.

\section{SARS-CoV-2 spike protein pseudovirions}

Pseudovirions were purchased from Sino Biological Inc. (Beijing, China), and were produced by transfection of 293T cells with psPAX2, pLenti-GFP, and plasmids encoding SARS-CoV-2 spike protein using polyetherimide. To infect $16 \mathrm{HBE}$ and $293 \mathrm{~T}-A C E 2$ cells with pseudovirions, the cells were seeded onto 96-well plates, pre-treated with CSE $(10 \%), \mathrm{BaP}(5 \mu \mathrm{mol} / \mathrm{L})$, or NNK $(5 \mu \mathrm{mol} / \mathrm{L})$ for $48 \mathrm{~h}$, followed by co-incubation with $100 \mu \mathrm{L}$ media containing pseudovirions for $48 \mathrm{~h}$. The cells were lysed with $60 \mu \mathrm{L}$ medium containing $50 \%$ Steady-glo (Promega) and measured by quantification of the luciferase activity using a Multi-Mode Reader (BioTek, Sunnyvale, CA, USA).

\section{Statistical analysis}

All statistical analyses were conducted using the software SPSS 26.0 for Windows (Chicago, IL, USA). Statistically significant differences were determined by Student's $t$-test or Fisher's exact test, and correlation between relative ACE2 and Skp2 expression levels was tested by Spearman correlation analysis. $P$ values less than 0.05 were considered statistically significant in all cases.

\section{Results}

\section{Tobacco smoke induces dual effects on ACE2}

SARS-CoV-2 enters target cells by binding to its receptor ACE2 and using the serine protease TMPRSS2 for viral spike (S) protein priming [14-16]. We tested the effects of cigarette smoking on $A C E 2$ expression, and reported that treatment of human normal lung epithelial $16 \mathrm{HBE}$ cells with CSE [14] at final concentrations of 5\% to $10 \%$ slightly upregulated $A C E 2$ at mRNA level (Fig. 1A), consistent with previous analyses of transcriptomic data sets $[17,18]$. We then tested the effects of tobacco smoking on ACE2 at protein level. Unexpectedly, we found that treatment of the cells with CSE at 5\% to $20 \%$ for $48 \mathrm{~h}$ (Fig. 1B) or at $10 \%$ for 48 to $72 \mathrm{~h}$ (Fig. 1C) significantly downregulated ACE2 at protein level, revealed by Western blot assay and densitometry analysis of immunoblot bands. The discrepancy in changes in mRNA and protein levels demonstrated the complicated effects of tobacco smoking on this receptor, and modulation of ACE2 protein may underlie the effect of smoking on SARS-CoV-2 infection.

\section{Tobacco carcinogens trigger ACE2 degradation}

The effects of several representative components of tobacco smoking on ACE2 were tested, and the results showed that treatment of $16 \mathrm{HBE}$ cells with nicotine at 2.5 to $10 \mu \mathrm{mol} / \mathrm{L}$ for $48 \mathrm{~h}$ or at $5 \mu \mathrm{mol} / \mathrm{L}$ for 24 to $72 \mathrm{~h} \mathrm{did} \mathrm{not}$ perturb ACE2 expression (Fig. S1A). Of note, group 1 carcinogen (carcinogenic to humans) $\mathrm{BaP}$ induced downregulation of ACE2 at 0.01 to $10 \mu \mathrm{mol} / \mathrm{L}$ treatment for $48 \mathrm{~h}$ (Fig. 1D). Treatment of $16 \mathrm{HBE}$ cells with $\mathrm{BaP}$ at 2.5 to $10 \mu \mathrm{mol} / \mathrm{L}$ for $48 \mathrm{~h}$ or at $5 \mu \mathrm{mol} / \mathrm{L}$ for 24 to $72 \mathrm{~h}$ significantly downregulated ACE2 expression (Fig. 1E). CSE and BaP did not affect the expression of TMPRSS2 or Furin (Fig. 1C and 1E). BaP downregulated ACE2 in normal human lung epithelial Beas-2B cells (Fig. 1F), human alveolar epithelial A549 cells, and human embryonic kidney 293T cells transfected with pCMV-ACE2-hygro plasmid (Fig. S1B). In macrophages derived from human monocytic cell line THP-1 by stimulation with phorbol 12myristate 13-acetate (PMA), the expression of ACE2 was low and BaP did not perturb its expression (Fig. S1C) but upregulated cytokines interferon- $\gamma(I F N \gamma)$, interleukin-1 $\alpha$ $(I L-1 \alpha), I L-1 \beta, I L-2, I L-6$, and tumor necrosis factor $\alpha$ $(T N F \alpha)$ that are associated with cytokine storm in COVID19 [19]. Moreover, another tobacco group 1 carcinogen NNK induced downregulation of ACE2 in 16HBE cells (Fig. 1G). On the contrary, the angiotensin receptor blockers azilsartan, candesartan, olmesartan but not eprosartan, induced upregulation of ACE2 (Fig. S2A), consistent with previous reports [20]. These compounds did not perturb the expression of TMPRSS2 or Furin in the cells (Fig. S2B).

\section{Tobacco carcinogen induces ubiquitination and degradation of ACE2}

$\mathrm{BaP}$ was used as a representative compound to dissect the mechanism of tobacco smoking-induced ACE2 downregulation at protein level. We showed that $\mathrm{BaP}$ treatment at $2.5-5 \mu \mathrm{mol} / \mathrm{L}$ for $48 \mathrm{~h}$ or at $5 \mu \mathrm{mol} / \mathrm{L}$ for $48-72 \mathrm{~h}$ slightly increased $A C E 2$ at mRNA level (Fig. 2A). BaP increased $A C E 2$ promoter-driven luciferase activity (Fig. 2B). We tested ACE2 protein stability by incubation of $16 \mathrm{HBE}$ cells with protein synthesis inhibitor cycloheximide (CHX), and found that treatment of the cells with CHX $(50 \mu \mathrm{g} / \mathrm{mL})$ for $12 \mathrm{~h}$ did not cause significant 


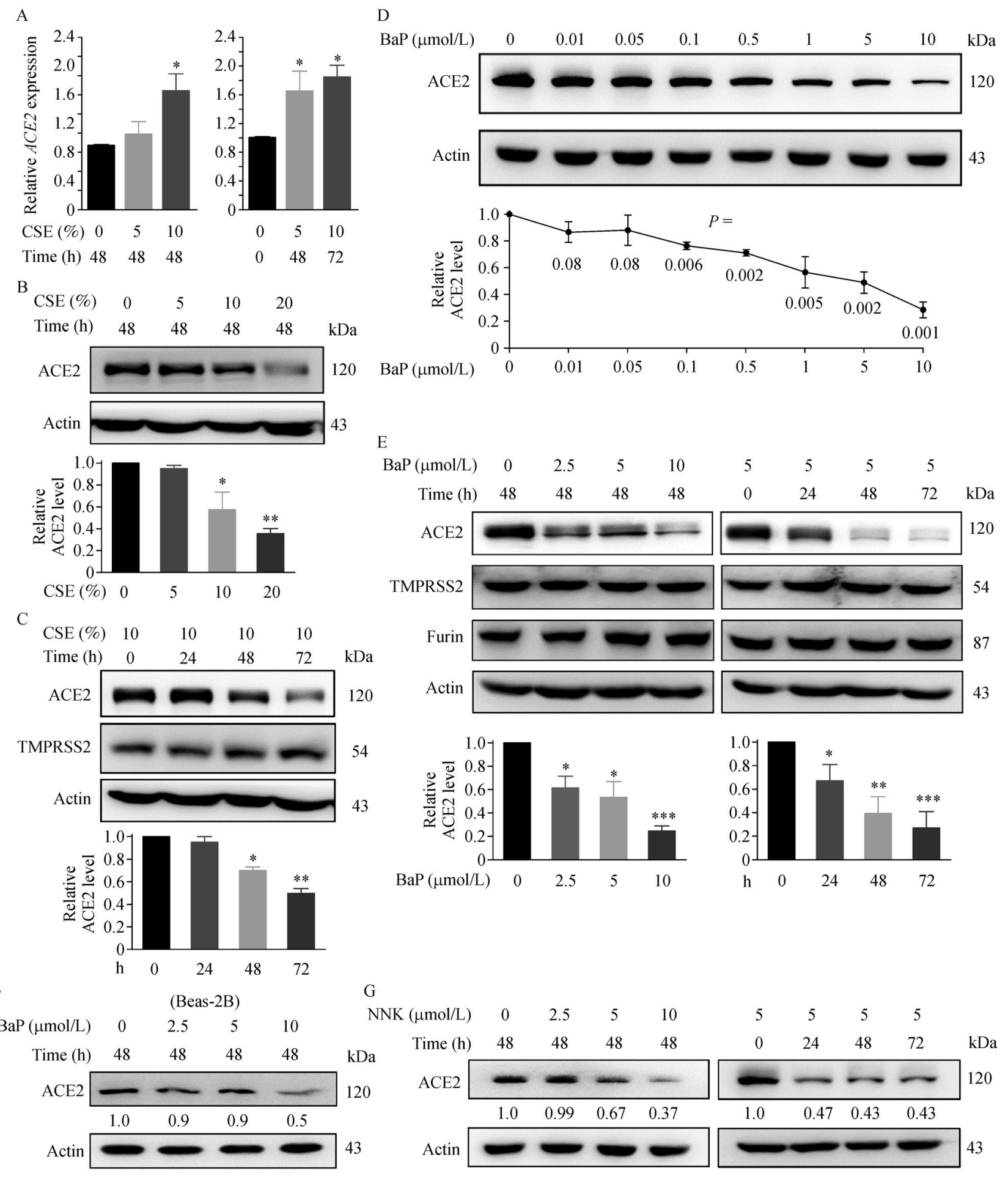

Fig. 1 Effects of tobacco carcinogens on ACE2 expression in lung epithelial cells. (A) 16HBE cells were treated with CSE at indicated protocols, lysed, RNA was extracted, and $A C E 2$ expression at mRNA level was evaluated by quantitative reverse transcription-polymerase chain reaction (RTPCR). $P$ values, Student's $t$-test, ${ }^{*} P<0.05$. (B, C) $16 \mathrm{HBE}$ cells were treated with CSE at indicated protocols, and ACE2 expression at protein level was detected by Western blot. The relative ACE2 levels were determined by densitometry analysis of immunoblot bands and normalized to Actin expression levels. $P$ values, Student's $t$-test, ${ }^{*} P<0.05,{ }^{* *} P<0.01$. (D, E) $16 \mathrm{HBE}$ cells were treated with BaP at indicated concentrations for $48 \mathrm{~h}$ (D) or at indicated protocols (E), lysed, and subjected to Western blot using indicated antibodies. The relative ACE2 levels were determined as described above. $P$ values, Student's $t$-test, ${ }^{*} P<0.05,{ }^{* *} P<0.01$, ${ }^{* * *} P<0.001$. (F) Beas-2B cells were treated with BaP, and ACE2 expression at protein level was detected by Western blot using cell lysates and indicated antibodies. Numbers under the Western blot bands are the relative expression values to Actin determined by densitometry analysis. (G) 16HBE cells were treated with NNK, lysed, and subjected to Western blot using indicated antibodies. Numbers under the Western blot bands are the relative ACE2 expression values to Actin. 


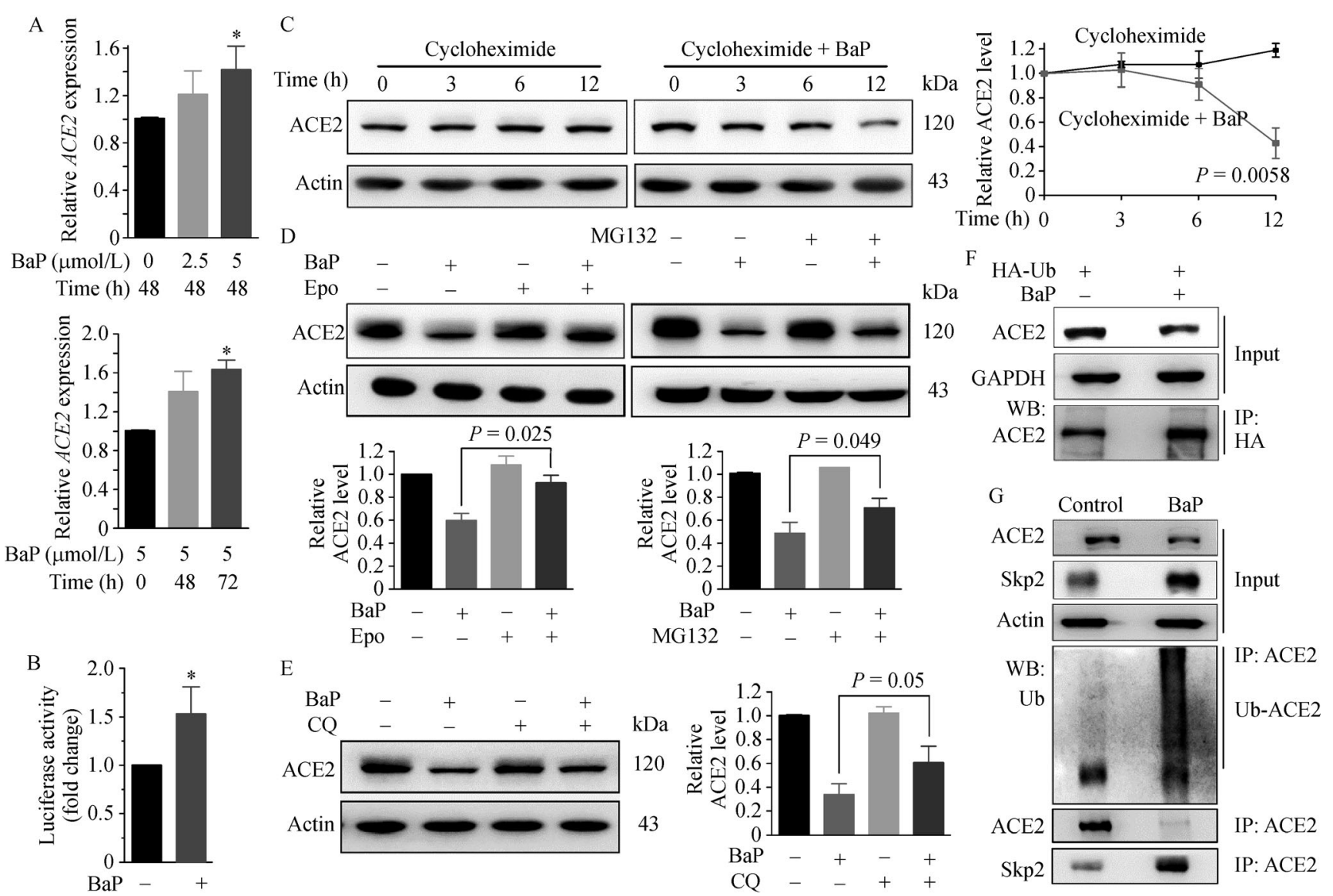

Fig. 2 BaP induces ACE2 degradation. (A) $16 \mathrm{HBE}$ cells were treated with $\mathrm{BaP}$, lysed, RNA was extracted, and $A C E 2$ expression at mRNA level was evaluated by quantitative RT-PCR. $P$ values, Student's $t$-test, $* P<0.05$. (B) The HLF cells were transfected with $A C E 2$ promoter-luciferase reporter construct, treated with $\mathrm{BaP}$ for $48 \mathrm{~h}$, and assessed by the luciferase assay. (C) $16 \mathrm{HBE}$ cells were treated with cycloheximide $(50 \mu \mathrm{g} / \mathrm{mL})$ in the absence or presence of $\mathrm{BaP}(5 \mu \mathrm{mol} / \mathrm{L})$, lysed, and subjected to Western blot assays. The relative ACE2 levels were determined as described above. $P$ values, Student's $t$-test. (D) $16 \mathrm{HBE}$ cells were pre-treated with $\mathrm{BaP}(5 \mu \mathrm{mol} / \mathrm{L})$ for $24 \mathrm{~h}$, subsequently co-incubated with epoxomicin (Epo; 10 $\mu \mathrm{mol} / \mathrm{L})$ or MG132 $(10 \mu \mathrm{mol} / \mathrm{L})$ for $12 \mathrm{~h}$, and then lysed for Western blot analyses. (E) 16HBE cells were treated with chloroquine (CQ; $40 \mu \mathrm{mol} / \mathrm{L})$ and $\mathrm{BaP}(5 \mu \mathrm{mol} / \mathrm{L})$ for $36 \mathrm{~h}$, and lysed for Western blot analyses. (F) $293 \mathrm{~T}$ cells were transfected with HA-Ub for $24 \mathrm{~h}$, treated with BaP $(5 \mu \mathrm{mol} / \mathrm{L})$ for additional $48 \mathrm{~h}$, lysed, and subjected to immunoprecipitation and immunoblot using indicated antibodies. Ub, ubiquitin. (G) $16 \mathrm{HBE}$ cells were treated with $\mathrm{BaP}(5 \mu \mathrm{mol} / \mathrm{L})$ for $48 \mathrm{~h}$, lysed, and subjected to immunoprecipitation and immunoblot using indicated antibodies.

downregulation of ACE2 (Fig. 2C), suggesting that this receptor was quite stable. However, combinatorial use of $\mathrm{CHX}$ and BaP led to downregulation of ACE2 at 6 to $12 \mathrm{~h}$, revealed by Western blot and densitometry analysis of protein bands (Fig. 2C). These results suggested that BaP may induce proteolytic degradation of ACE2. Proteasome and lysosome are two critical sites for degradation of ubiquitinated substrate proteins, and we found that proteasome inhibitors, epoxomicin and MG132, (Fig. 2D) and lysosome inhibitor, chloroquine (CQ; Fig. 2E), inhibited BaP-induced ACE2 downregulation. In cells transfected with hemagglutinin-ubiquitin (HA-Ub) plasmid [21], BaP induced downregulation of ACE2 and enhanced Ub-ACE2 binding affinity (Fig. 2F). In 16HBE cells treated with $5 \mu \mathrm{mol} / \mathrm{L}$ Bap for $48 \mathrm{~h}, \mathrm{BaP}$ downregulated ACE2 and potentiated ubiquitination of ACE2 (Fig. 2G).

\section{Skp2 mediates carcinogen-induced ACE2 ubiquitination and degradation}

To identify the E3 ubiquitin ligase that mediates BaPinduced ACE2 degradation, the expression of several critical E3 ligases, e.g., the F-box (40 amino acid motif)containing E3 ligase S-phase kinase associated protein 2 (Skp2), $\beta$-transducin repeat containing E3 ubiquitin protein ligase ( $\beta$-TRCP), the nuclear interaction partner of ALK (NIPA), the RING finger and WD repeat domain 3 (RFWD3), and deubiquitinase ubiquitin-specific protease 10 (USP10) were tested in cells treated with BaP. We showed that upon BaP treatment, the expression of Skp2 [22] was drastically upregulated at protein (Fig. 3A) and mRNA (Fig. 3B) levels. However, the expression of $\beta$-TRCP, NIPA, RFWD3, USP10, and Skp1 which is a core subunit of the Skp1-Cull-F-box protein 


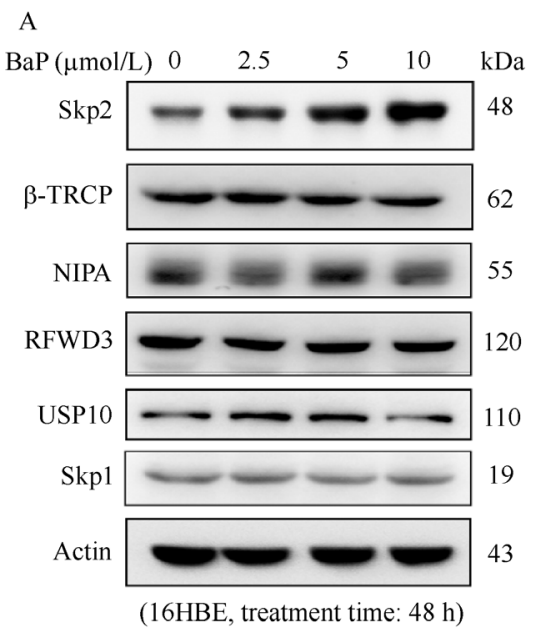

C
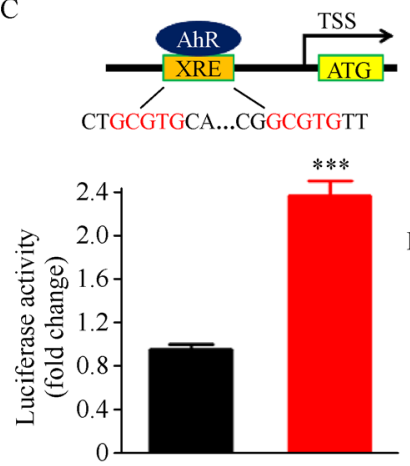

$\mathrm{BaP}(5 \mu \mathrm{mol} / \mathrm{L})-$

E
B
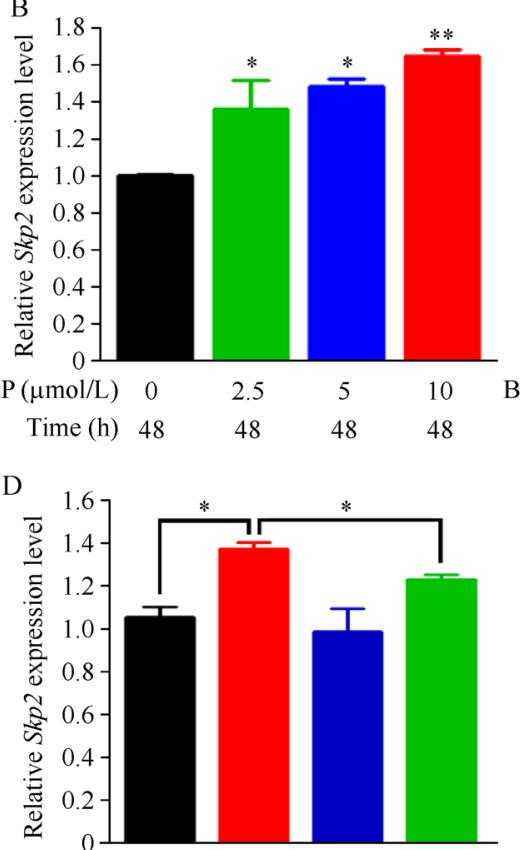

$\mathrm{BaP}(5 \mu \mathrm{mol} / \mathrm{L})$

ANF

$\mathrm{BaP}(5 \mu \mathrm{mol} / \mathrm{L})$

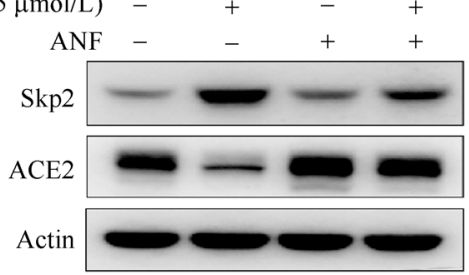

G
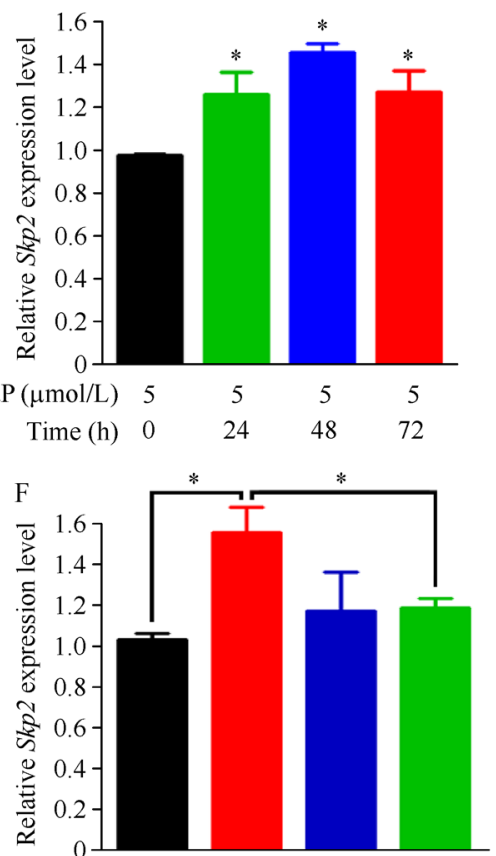

$+\quad \mathrm{BaP}(5 \mu \mathrm{mol} / \mathrm{L})$

CH223191

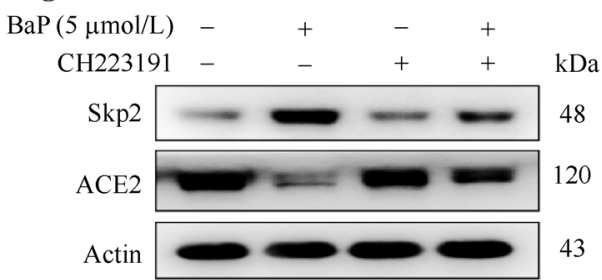

$\mathrm{H}$
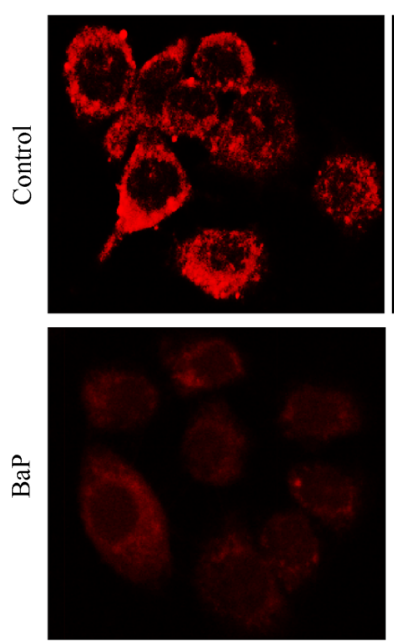

Skp2
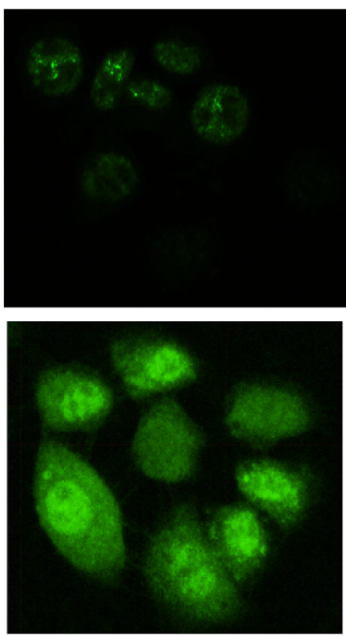

DAPI
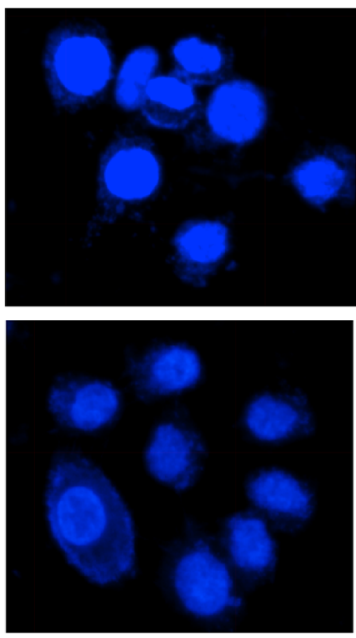

Merge
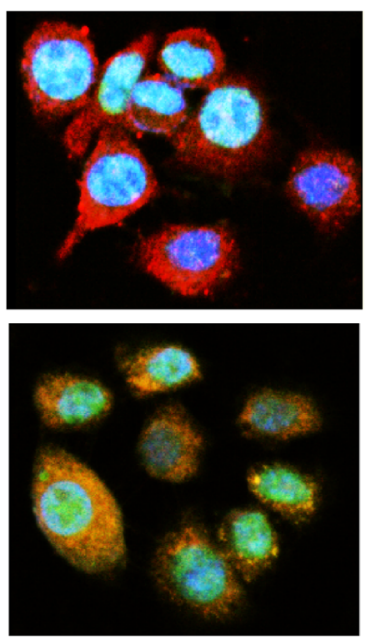

Fig. 3 BaP induces an AhR-dependent Skp2 upregulation. (A) $16 \mathrm{HBE}$ cells were treated with $\mathrm{BaP}$ at indicated concentrations for $48 \mathrm{~h}$, lysed, and subjected to immunoblot using indicated antibodies. (B) $16 \mathrm{HBE}$ cells were treated with BaP as indicated, lysed, RNA were extracted, and analyzed by quantitated RT-PCR. Student's $t$-test, ${ }^{*} P<0.05 ;{ }^{* *} P<0.01$. Error bars, SD. (C) ACE2 is a target gene of AhR. The upper panel shows the AhR binding site of $S k p 2$ promoter. TSS, transcription start site. Lower panel, $16 \mathrm{HBE}$ cells were transfected with the XRE element of $S k p 2$ promoterluciferase reporter construct, treated with BaP for $48 \mathrm{~h}$, and assessed by the luciferase assays. Student's $t$-test, $* * * P<0.001$. Error bars, SD. (D-G) 16HBE cells were treated with BaP in the absence or presence of AhR antagonist ANF (D, E) or CH223191 (F, G), lysed, and analyzed by quantitative RT-PCR (D, F) or Western blot (E, G). Student's $t$-test, $* P<0.05$. Error bars, SD. (H) The expression of ACE2 and Skp2 in 16HBE cells treated with vehicle control (DMSO) or BaP at $10 \mu \mathrm{mol} / \mathrm{L}$ for $48 \mathrm{~h}$. The cells were harvested and detected by immunofluorescence assays using indicated antibodies. 
(SCF) complex, was not significantly perturbed by $\mathrm{BaP}$ treatment (Fig. 3A).

The helix-loop-helix transcription factor aryl hydrocarbon receptor (AhR) plays a key role in the regulation of biological responses to polycyclic aromatic hydrocarbons (PAHs) and dioxin [23]. By analyzing its promoter sequence, we found that $\operatorname{Skp} 2$ harbors two xenobioticresponsive elements (XRE), 5'-GCGTG-3' and 5'GCGTG-3', in its promoter region (Fig. 3C), indicating that it is a target gene of AhR. We showed that $\mathrm{BaP}$ increased $S k p 2$ promoter-driven luciferase activity (Fig. 3C), and AhR inhibitors $\alpha$-naphthoflavone (ANF; Fig. 3D and 3E) and $\mathrm{CH} 223191$ (Fig. 3F and 3G) suppressed BaP-induced Skp2 upregulation at both mRNA (Fig. 3D and 3F) and protein (Fig. 3E and 3G) levels, and inhibited BaP-induced ACE2 downregulation (Fig. 3D-3G).

We showed that in $16 \mathrm{HBE}$ cells upon $\mathrm{BaP}$ treatment, Skp2 upregulation was concomitantly detected with downregulation of ACE2, and co-localization of ACE2 and Skp2 was seen within the cells (Fig. 3H). Consistent with these observations, ACE2 expression was negatively associated with Skp2 expression in several cell lines (Fig. S3). By co-immunoprecipitation assay, we reported that Skp2 could bind to ACE2 but not RFWD3 in 16HBE and pCMV-ACE2-transfected 293T (Fig. 2G, Fig. 4A) cells in the absence and presence of $\mathrm{BaP}$ treatment, and $\mathrm{BaP}$ treatment enhanced ACE2-Skp2 binding affinity. By expression and purification of truncated Skp2 mutants (Fig. 4B), we showed that two domains (183-292 and 293-424 amino acids) in C-terminal of Skp2 were responsible for interaction with ACE2, whereas the Nterminal (1-182 amino acids) of this E3 ligase was unable to bind ACE2 (Fig. 4C). Exogenous Skp2 also bound ACE2 and caused enhanced ubiquitination and downregulation of ACE2 in 16HBE and 293T-ACE2 cells (Fig. 4D). By CHX chase experiment, we showed that ectopic expression of Skp2 induced decrease of ACE2 stability in 16HBE cells (Fig. 4E). Meanwhile, knockdown of Skp2 by specific small interfering RNA (siRNA) suppressed BaP-induced proteolytic degradation as well as ubiquitination of ACE2 (Fig. 4F and 4G). Silencing of Skp2 by siSkp2 attenuated BaP-induced ACE2 ubiquitination and degradation in 293T-ACE2 cells (Fig. 4H). To further determine whether Skp2 could induce ACE2 ubiquitination, an in vitro ubiquitination assay was performed using Flag-ACE2 and Flag-Skp2 proteins purified from 293T cells, and the results showed that Skp2 was able to trigger ACE2 ubiquitination (Fig. 4I). In in vitro ubiquitination assay using recombinant carrier free ACE2 and Skp2 proteins bought from R\&D Systems, we confirmed that Skp2 was able to trigger ACE2 ubiquitination (Fig. 4J), demonstrating that Skp2 is the E3 ligase for ACE2 ubiquitination and degradation.

\section{Tobacco carcinogens induced ACE2 downregulation in vivo}

To test the in vivo effect of tobacco smoking on ACE2 expression, immunohistochemistry (IHC) assay was performed on lung biopsy samples of patients with benign diseases (Table S1). The results showed that ACE2 was expressed on membrane and cytoplasm of the cells, and smokers had much lower ACE2 than non-smokers (Fig. $5 \mathrm{~A}$ and $5 \mathrm{~B})$. On the contrary, the expression of Skp2 was low in non-smokers and high in smokers (Fig. 5A and 5B), showing a negative correlation trend with ACE2 in the patients. In another setting, Western blot analysis was performed using lysates of specimens harvested from normal lung tissues $5 \mathrm{~cm}$ away from tumor tissues of patients with lung cancer (Table S2), and we reported that in smoker patients the expression of ACE2 was lower whereas Skp2 was higher than those in non-smoker patients (Fig. 5C and 5D). The relationship between ACE2 and Skp2 expression levels was analyzed by Spearman analysis, and a negative correlation between the two variables was detected (Fig. 5E).

To confirm these observations, the $\mathrm{A} / \mathrm{J}$ mice were exposed to cigarette smoke with filtered conditioned air of $750 \mu \mathrm{g}$ total particulate matter per liter for 20 days [14], and lung tissues of the mice were stained with anti-ACE2 and anti-Skp2 antibodies. IHC assays (Fig. 5F) and related IRS (Fig. 5G) showed that ACE2 was lower while Skp2 was higher in mice exposed to tobacco smoking than in mice exposed to clean air. These results were confirmed by immunofluorescence (Fig. 5H) and Western blot/related densitometry assays (Fig. 5I and 5J) of these lung tissues. In mice treated with BaP at $100 \mathrm{mg} / \mathrm{kg}$ twice a week for 5 weeks, the ACE2 expression in lung tissues was decreased compared with that in mice treated with vehicle control (Fig. $5 \mathrm{~K}$ and $5 \mathrm{~L}$ ). Treatment with $\mathrm{NNK}$ at $50 \mathrm{mg} / \mathrm{kg}$ twice a week for 5 weeks also caused downregulation of ACE2 in lung tissues of the mice (Fig. $5 \mathrm{~K}$ and $5 \mathrm{~L}$ ).

\section{Effects of tobacco carcinogens on SARS-CoV-2 spike protein pseudovirus infection}

The effects of CSE on viral entry were tested in 16HBE cells using the SARS-CoV-2 spike (S) protein pseudovirus [24], and the results showed that while the pseudovirion was able to enter into the cells, treatment with CSE at $10 \%$ for $48 \mathrm{~h}$ reduced the entry of pseudovirus by approximately $25 \%$, revealed by relative luciferase activity (Fig. 6A). BaP $(5 \mu \mathrm{mol} / \mathrm{L})$ and $\mathrm{NNK}(5 \mu \mathrm{mol} / \mathrm{L})$ inhibited SARS-CoV-2 S protein pseudovirus from entry into the cells by $35 \%$ and $30 \%$, respectively (Fig. 6A). In $293 \mathrm{~T}$ cells transfected with pCMV-ACE2-hygro plasmid, treatment with CSE, NNK, and $\mathrm{BaP}$ reduced pseudovirus entry by $15 \%, 30 \%$, and $40 \%$, respectively (Fig. 6B). 


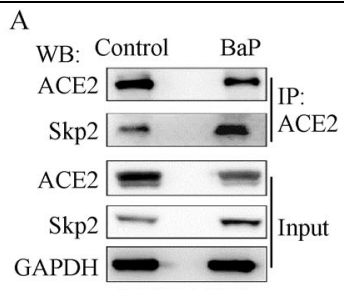

(293T-ACE2)

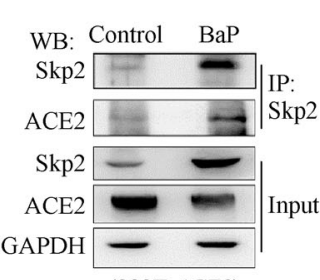

(293T-ACE2)

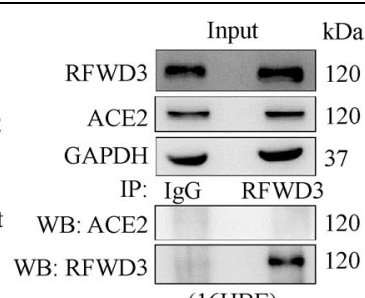

(16HBE)
B

$\Delta 1 \longdiv { \square }$

$\Delta 3 \longdiv { \square }$

$\Delta 4 \longdiv { \square } \square$

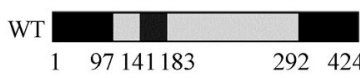

C
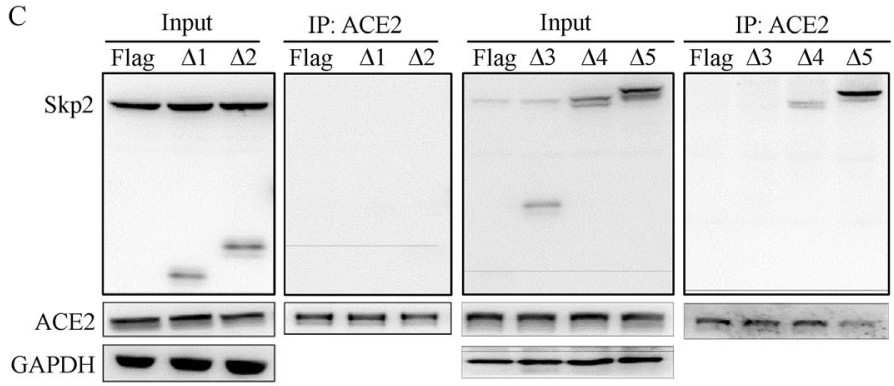

GAPDH
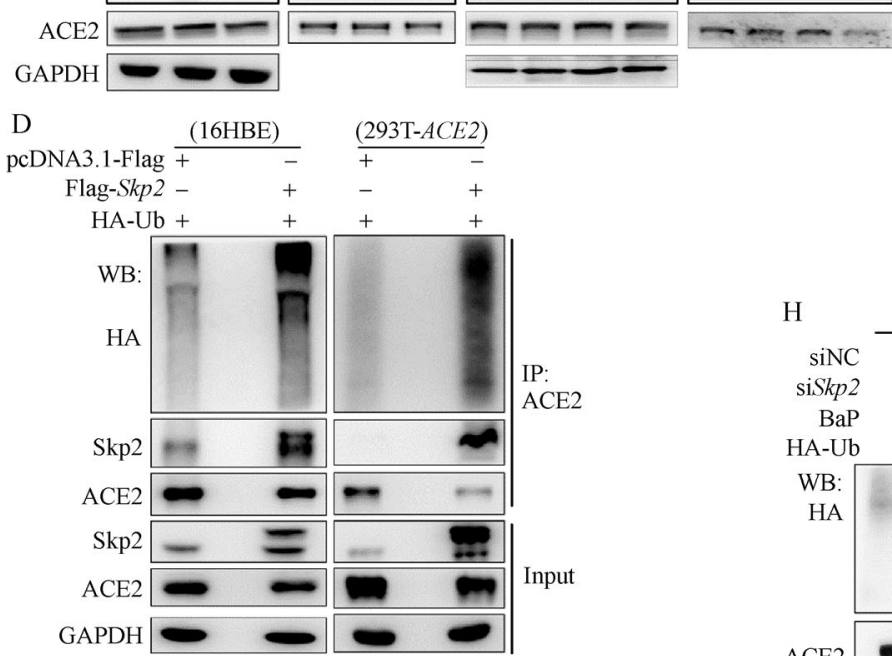

E Flag $++++-\quad+-$

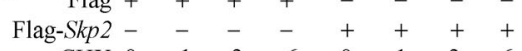

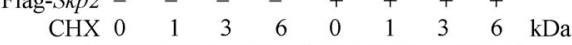
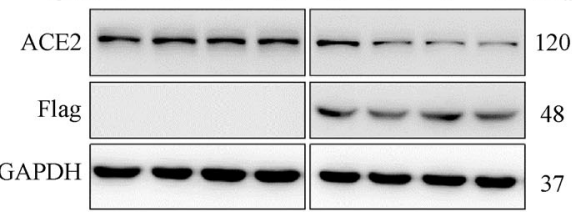
20

F

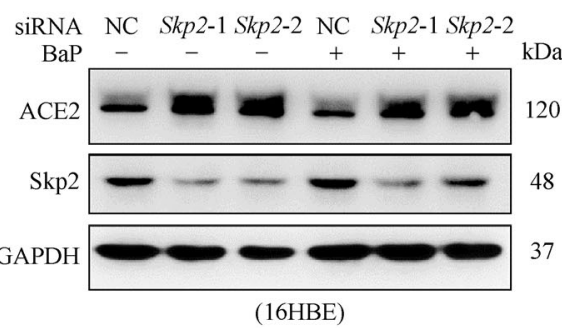

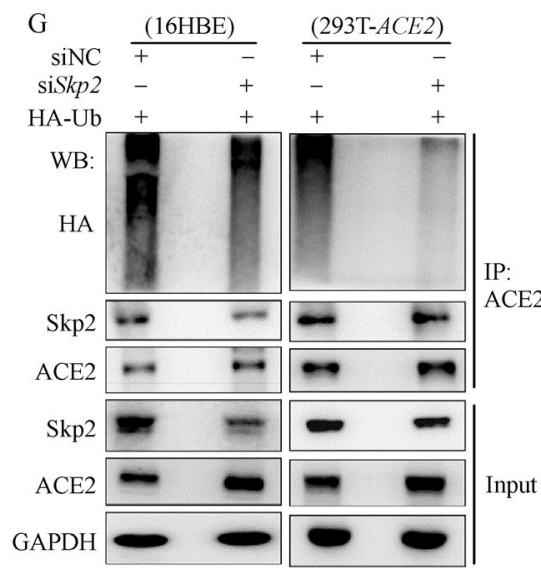
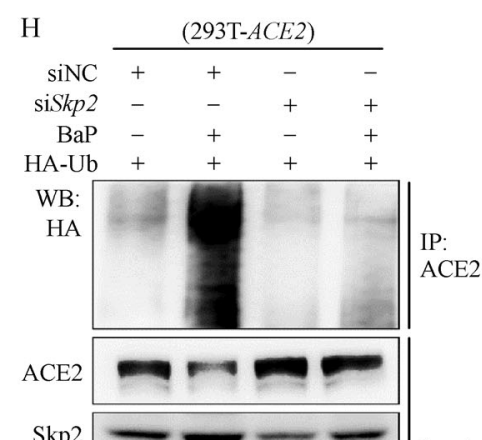

$\operatorname{Skp} 2-\longrightarrow$ Input

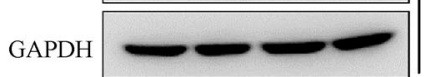

$\mathrm{J}$

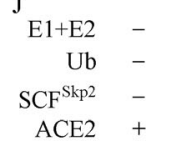

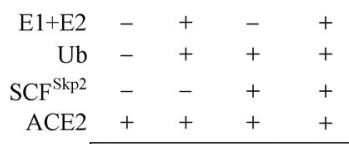

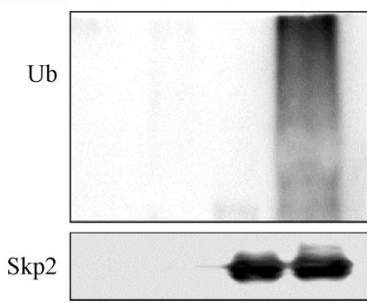

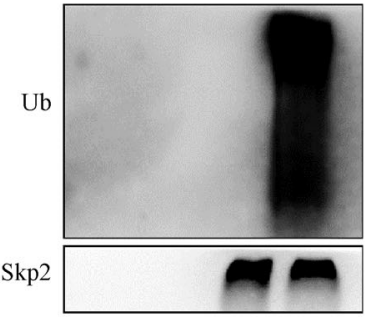

Fig. 4 Skp2 mediates ubiquitination and degradation of ACE2 induced by BaP. (A) 293T-ACE2 cells were treated with BaP (5 $\mu$ mol/L) for 48 h, lysed, and subjected to immunoprecipitation and immunoblot using indicated antibodies. Lysates of 16HBE cells were subjected to immunoprecipitation and immunoblot assays using indicated antibodies (right panel). (B, C) Schematic representation of $S k p 2$ truncated mutants (B), which were transfected into 293T- $A C E 2$ cells for protein purification and subsequent immunoblotting assays using indicated antibodies (C). (D) $16 \mathrm{HBE}$ and 293T-ACE2 cells were transfected with Flag-Skp2 and HA-Ub for $48 \mathrm{~h}$, lysed, and subjected to immunoprecipitation and immunoblot using indicated antibodies. (E) 16HBE cells were transfected with Flag-Skp2, treated with CHX, lysed, and subjected to immunoblot using indicated antibodies. (F) $16 \mathrm{HBE}$ cells were transfected with siSkp2 for $24 \mathrm{~h}$, followed by co-incubation with BaP $(5 \mu \mathrm{mol} / \mathrm{L})$ for $48 \mathrm{~h}$, lysed, and subjected to immunoblot using indicated antibodies. (G) 16HBE and 293T- $A C E 2$ cells were transfected with siSkp2 and HA-Ub for $48 \mathrm{~h}$, lysed, and subjected to immunoprecipitation and immunoblot using indicated antibodies. (H) 293T-ACE2 cells were transfected with siSkp2 and HA-Ub for $48 \mathrm{~h}$, followed by treatment with $\mathrm{BaP}$ at $5 \mu \mathrm{mol} / \mathrm{L}$ for additional $48 \mathrm{~h}$. The cells were lysed, and subjected to immunoprecipitation and immunoblot using indicated antibodies. (I) In vitro ubiquitination assay using Flag-SCF ${ }^{\text {Skp2 }}$ and Flag-ACE2 purified from 293T cells. (J) In vitro ubiquitination assay using recombinant carrier free ACE2 and $\mathrm{SCF}^{\mathrm{Skp} 2}$ proteins bought from R\&D Systems. 


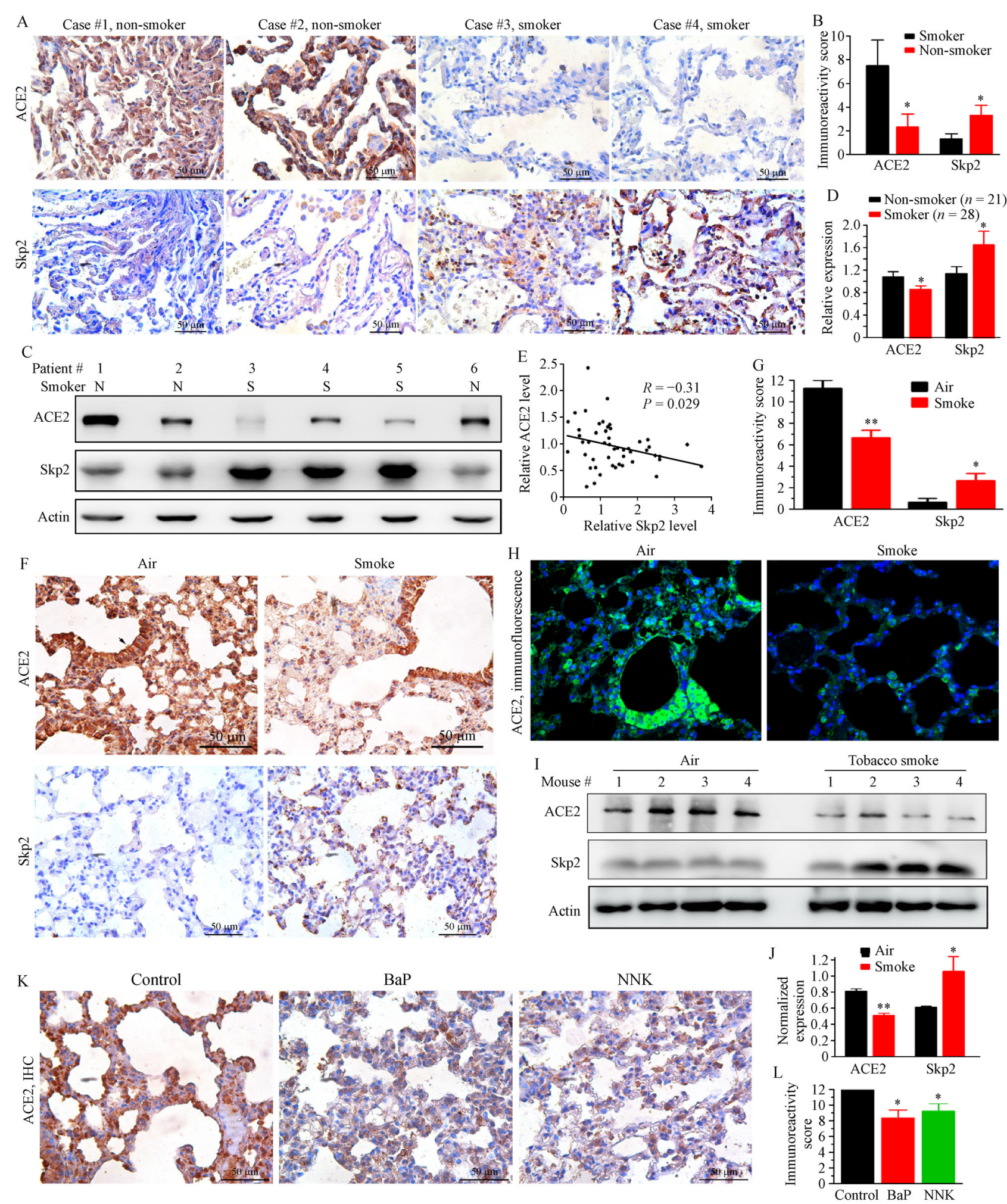

Fig. 5 Tobacco smoke and BaP induce downregulation of ACE2 in vivo. (A, B) Immunohistochemistry analysis of lung biopsy samples of patients with benign disease (A), and immunoreactivity score of ACE2 and Skp2 was calculated (B). (C, D) Western blot assays of normal lung tissues harvested $5 \mathrm{~cm}$ away from tumor tissues of patients with lung cancer $(\mathrm{C})$ and quantification of ACE2 and Skp2 determined by densitometry analyses of immunoblot bands (D). (E) Spearman correlation analysis of ACE2 and Skp2 relative expression levels of the patients using the results of (D). $(\mathrm{F}, \mathrm{G})$ Immunohistochemistry analyses of lung tissues of mice exposed to clean air or tobacco smoke (F), and immunoreactivity score of ACE2 and Skp2 was calculated (G). Arrow, ciliated cells also express ACE2. (H) Immunofluorescence assays of lung tissues of mice exposed to clean air or tobacco smoke. (I, J) Western blot assays of lung tissues of mice exposed to clean air or tobacco smoke (I) and quantification of ACE2 and Skp2 determined by densitometry analyses of immunoblot bands $(\mathrm{J})$. (K, L) Immunohistochemistry analyses of lung tissues of mice treated with vehicle control, BaP, or NNK (K). Immunoreactivity score of ACE2 was calculated (L). 

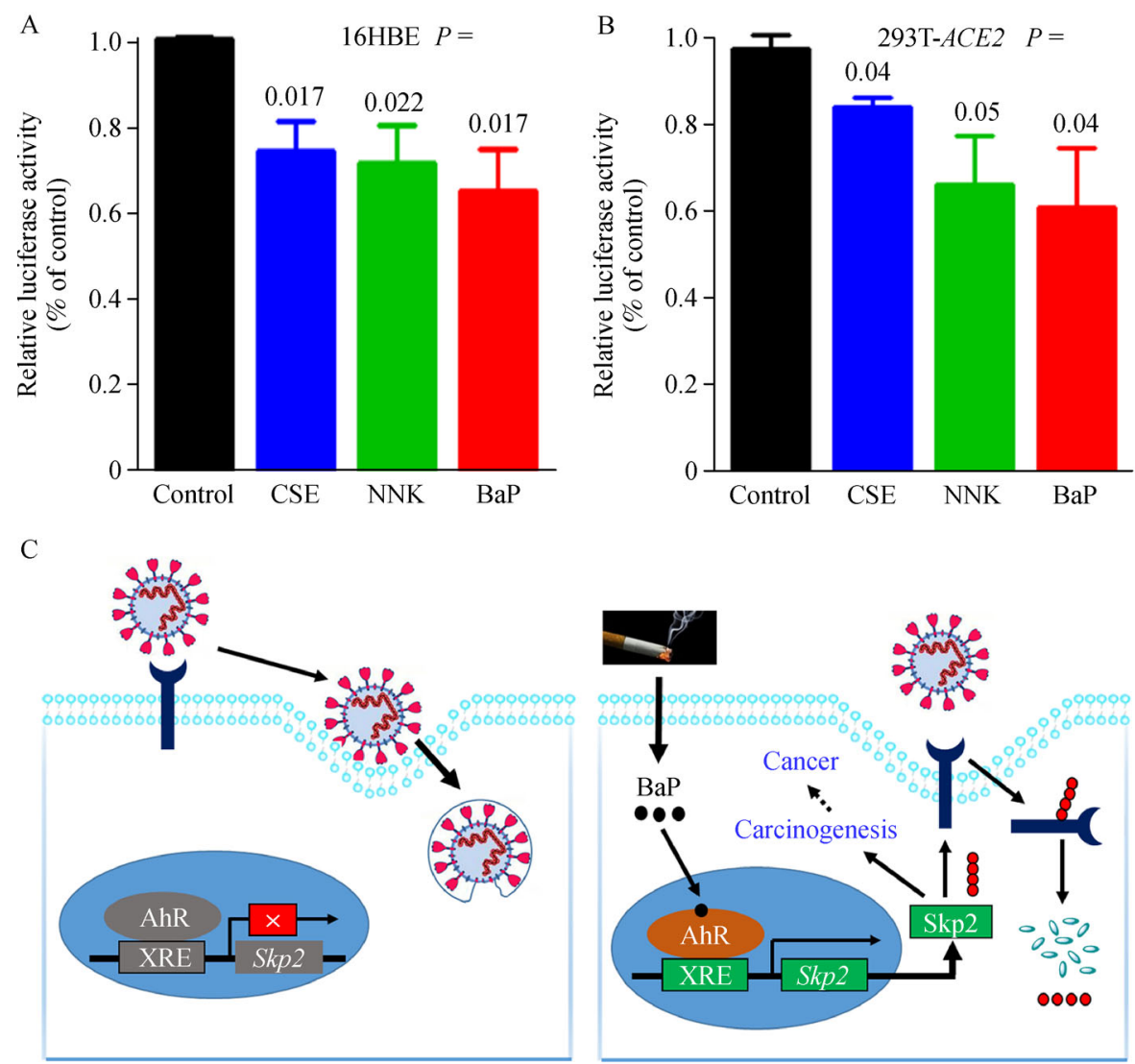

Fig. 6 Inhibition of SARS-CoV-2 S protein pseudoviron entry by CSE, BaP, and NNK. (A) Entry of SARS-CoV-2 S protein pseudovirions into $16 \mathrm{HBE}$ cells treated with indicated agents. (B) Entry of SARS-CoV-2 S protein pseudovirions into $293 \mathrm{~T}-A C E 2$ cells treated with indicated agents. (C) Schematic representation of tobacco smoke-induced ACE2 degradation.

\section{Discussion}

Tobacco smoke accounts for more than 8 million deaths each year worldwide, with 7 million deaths from direct tobacco use and 1.2 million deaths of non-smokers being exposed to second-hand smoke [25]. There is strong evidence for a causal association between smoking and 29 diseases (14 types of cancers, 7 categories of cardiovascular disease, 3 categories of respiratory disease, diabetes, renal failure, infections, intestinal ischemia, and liver cirrhosis) [26]. Tobacco and smoking contain more than 70 carcinogens and cause cancers via complicated mechanisms $[27,28]$. Therefore, great efforts should be made to reduce tobacco use and help smokers to quit.

Effective drugs for COVID-19 remain rare, and vaccines for SARS-CoV-2 are still under investigation [19]. CSE inhibits SARS-CoV-2 S protein pseudovirus infection, supporting the clinical findings that smokers might have a lower probability of developing SARS-CoV-2 infection as compared to the general population $[7,8]$. Among the tobacco compounds, $\mathrm{BaP}$ and $\mathrm{NNK}$, but not nicotine, inhibit SARS-CoV-2 $\mathrm{S}$ protein pseudovirion from infection of the cells. These results do not suggest an efficacy of nicotine in prevention/treatment of COVID-19. Both BaP and NNK are notorious carcinogens that cause comprehensive hazardous effects on humans and induce carcinogenesis [28]. $\mathrm{BaP}$ also induces upregulation of Skp2, an oncoprotein that plays a pivotal role in cell cycle progression and proliferation [29]. Therefore, the generalized advice to quit smoking as a measure to improve health risk remains valid, because it is the carcinogens that are responsible for ACE2 degradation.

ACE2 is a glycoprotein metalloprotease that exists in membrane-bound and soluble forms and has enzymatic and non-enzymatic functions. It is expressed in type II alveolar cells, myocardial cells, proximal tubule cells of kidney, ileum and esophagus epithelial cells, bladder urothelial cells, and other types of cells [16]. We showed that tobacco carcinogens exert dual effects on ACE2, i.e., upregulation at mRNA and downregulation at protein levels, in normal human lung epithelial cells. This discrepancy was consistent with studies into mRNAprotein relationship showing poor correlation between the two kinds of molecules [30]. A study reports that 
angiotensin II (Ang-II) treatment induces ACE2 internalization into lysosomes where it is degraded [31]. We show that lysosome is partially responsible for $\mathrm{BaP}$ triggered ACE2 degradation, because lysosome inhibitor chloroquine partially rescues ACE2 from $\mathrm{BaP}$-induced degradation. Proteasome also has a role in ACE2 catabolism, since epoxomicin and MG132 partially suppress ACE2 degradation. The fact that inhibition of either proteasome or lysosome can partially but not completely block the degradation of ACE2 suggests that the both organelles are critical to ACE2 catabolism, and the role of other forms of post-translational modification (e.g., phosphorylation and glycosylation) in ACE2 catabolism warrants further investigation. Currently, how NNK downregulates ACE2 remains unclear. We show that $\mathrm{BaP}$ induces a significant upregulation of Skp2, which interacts with ACE2 and induces ubiquitination and degradation of the substrate. Therefore, our results partially unveil the mechanisms of action of tobacco carcinogens on ACE2 (Fig. 6C). This receptor is required to maintain lung and cardiovascular functions [20], whether ACE2 proteolysis is responsible for severity of patients with COVID-19 needs to be determined in the future studies.

\section{Acknowledgements}

This work was jointly supported by the National Key Research and Development Program of China (Nos. 2020YFA0803300 and 2018YFC1313600), the National Natural Science Funds for Distinguished Young Scholar (No. 81425025), the Key Project of the National Natural Science Foundation of China (No. 81830093), the CAMS Innovation Fund for Medical Sciences (CIFMS; No. 2019-I2M-1-003), and the National Natural Science Foundation of China (Nos. 81672765 and 81802796).

\section{Compliance with ethics guidelines}

Guizhen Wang, Qun Zhao, Hui Zhang, Fan Liang, Chen Zhang, Jun Wang, Zhenyin Chen, Ran Wu, Hong Yu, Beibei Sun, Hua Guo, Ruie Feng, Kaifeng Xu, and Guangbiao Zhou declare that they have no conflict of interest. All procedures followed were in accordance with the ethical standards of the responsible committee on human experimentation (institutional and national) and with the Helsinki Declaration of 1975 as revised in 2000. Additional informed consent was obtained from all patients whose identifying information is included in this article.

Electronic Supplementary Material Supplementary material is available in the online version of this article at https://oi.org/ $10.1007 / \mathrm{s} 11684-021-0837-6$ and is accessible for authorized users.

\section{References}

1. COVID-19 Dashboard by the Center for Systems Science and
Engineering (CSSE) at Johns Hopkins University. (JHU). 2020. https://www.arcgis.com/apps/opsdashboard/index.html\#/bda7594740fd40299423467b48e9ecf6 (accessed December 8, 2020)

2. World Health Organization. Smoking and COVID-19. 2020. https:// www.who.int/news-room/commentaries/detail/smoking-and-covid19 (accessed December 8, 2020)

3. Lippi G, Henry BM. Active smoking is not associated with severity of coronavirus disease 2019 (COVID-19). Eur J Intern Med 2020; 75:107-108

4. Farsalinos K, Barbouni A, Niaura R. Systematic review of the prevalence of current smoking among hospitalized COVID-19 patients in China: could nicotine be a therapeutic option? Intern Emerg Med 2020; 15(5): 845-852

5. CDC COVID-19 Response Team. Preliminary estimates of the prevalence of selected underlying health conditions among patients with coronavirus disease 2019-United States, February 12 - March 28, 2020. MMWR Morb Mortal Wkly Rep 2020; 69(13): 382-386

6. Guan WJ, Ni ZY, Hu Y, Liang WH, Ou CQ, He JX, Liu L, Shan H, Lei CL, Hui DSC, Du B, Li LJ, Zeng G, Yuen KY, Chen RC, Tang CL, Wang T, Chen PY, Xiang J, Li SY, Wang JL, Liang ZJ, Peng YX, Wei L, Liu Y, Hu YH, Peng P, Wang JM, Liu JY, Chen Z, Li G, Zheng ZJ, Qiu SQ, Luo J, Ye CJ, Zhu SY, Zhong NS; China Medical Treatment Expert Group for Covid-19. Clinical characteristics of coronavirus disease 2019 in China. N Engl J Med 2020; 382 (18): 1708-1720

7. Miyara M, Tubach F, Pourcher V, Morelot-Panzini C, Pernet J, Haroche J, Lebbah S, Morawiec E, Gorochov G, Caumes E, Hausfater P, Combes A, Similowski T, Amoura Z. Low incidence of daily active tobacco smoking in patients with symptomatic COVID19 infection. Qeios 2020; 10.32388/WPP19W

8. Vardavas CI, Nikitara K. COVID-19 and smoking: a systematic review of the evidence. Tob Induc Dis 2020; 18: 20

9. Gebel S, Diehl S, Pype J, Friedrichs B, Weiler H, Schüller J, Xu H, Taguchi K, Yamamoto M, Müller T. The transcriptome of $\mathrm{Nrf}^{-/}$ mice provides evidence for impaired cell cycle progression in the development of cigarette smoke-induced emphysematous changes. Toxicol Sci 2010; 115(1): 238-252

10. Wang GZ, Cheng X, Zhou B, Wen ZS, Huang YC, Chen HB, Li GF, Huang ZL, Zhou YC, Feng L, Wei MM, Qu LW, Cao Y, Zhou GB. The chemokine CXCL13 in lung cancers associated with environmental polycyclic aromatic hydrocarbons pollution. eLife 2015; 4 : e09419

11. Carnevali S, Petruzzelli S, Longoni B, Vanacore R, Barale R, Cipollini M, Scatena F, Paggiaro P, Celi A, Giuntini C. Cigarette smoke extract induces oxidative stress and apoptosis in human lung fibroblasts. Am J Physiol Lung Cell Mol Physiol 2003; 284(6): L955-L963

12. Wang GZ, Cheng X, Li XC, Liu YQ, Wang XQ, Shi X, Wang ZY, Guo YQ, Wen ZS, Huang YC, Zhou GB. Tobacco smoke induces production of chemokine CCL20 to promote lung cancer. Cancer Lett 2015; 363(1): 60-70

13. Liu Z, Ma L, Wen ZS, Hu Z, Wu FQ, Li W, Liu J, Zhou GB. Cancerous inhibitor of PP2A is targeted by natural compound celastrol for degradation in non-small-cell lung cancer. Carcinogenesis 2014; 35(4): 905-914

14. Wang GZ, Zhang L, Zhao XC, Gao SH, Qu LW, Yu H, Fang WF, Zhou YC, Liang F, Zhang C, Huang YC, Liu Z, Fu YX, Zhou GB. 
The Aryl hydrocarbon receptor mediates tobacco-induced PD-L1 expression and is associated with response to immunotherapy. Nat Commun 2019; 10(1): 1125

15. Hoffmann M, Kleine-Weber H, Schroeder S, Krüger N, Herrler T, Erichsen S, Schiergens TS, Herrler G, Wu NH, Nitsche A, Müller MA, Drosten C, Pöhlmann S. SARS-CoV-2 cell entry depends on ACE2 and TMPRSS2 and is blocked by a clinically proven protease inhibitor. Cell 2020; 181(2): 271-280

16. Zou X, Chen K, Zou J, Han P, Hao J, Han Z. Single-cell RNA-seq data analysis on the receptor ACE2 expression reveals the potential risk of different human organs vulnerable to $2019-\mathrm{nCoV}$ infection. Front Med 2020; 14(2): 185-192

17. Cai G, Bossé Y, Xiao F, Kheradmand F, Amos CI. Tobacco smoking increases the lung gene expression of ACE2, the receptor of SARS-CoV-2. Am J Respir Crit Care Med 2020; 201(12): $1557-$ 1559

18. Smith JC, Sausville EL, Girish V, Yuan ML, Vasudevan A, John $\mathrm{KM}$, Sheltzer JM. Cigarette smoke exposure and inflammatory signaling increase the expression of the SARS-CoV-2 receptor ACE2 in the respiratory tract. Dev Cell 2020; 53(5): 514-529.e3

19. Zhou G, Chen S, Chen Z. Advances in COVID-19: the virus, the pathogenesis, and evidence-based control and therapeutic strategies. Front Med 2020; 14(2): 117-125

20. Gheblawi M, Wang K, Viveiros A, Nguyen Q, Zhong JC, Turner AJ, Raizada MK, Grant MB, Oudit GY. Angiotensin-converting enzyme 2: SARS-CoV-2 receptor and regulator of the reninangiotensin system: celebrating the 20th anniversary of the discovery of ACE2. Circ Res 2020; 126(10): 1456-1474

21. Kamitani T, Kito K, Nguyen HP, Yeh ETH. Characterization of NEDD8, a developmentally down-regulated ubiquitin-like protein. J Biol Chem 1997; 272(45): 28557-28562

22. Zhang H, Kobayashi R, Galaktionov K, Beach D. p19Skp1 and p45Skp2 are essential elements of the cyclin A-CDK2 S phase kinase. Cell 1995; 82(6): 915-925

23. Tsay JJ, Tchou-Wong KM, Greenberg AK, Pass H, Rom WN. Aryl hydrocarbon receptor and lung cancer. Anticancer Res 2013; 33(4): $1247-1256$
24. Ou X, Liu Y, Lei X, Li P, Mi D, Ren L, Guo L, Guo R, Chen T, Hu J, Xiang Z, Mu Z, Chen X, Chen J, Hu K, Jin Q, Wang J, Qian Z. Characterization of spike glycoprotein of SARS-CoV-2 on virus entry and its immune cross-reactivity with SARS-CoV. Nat Commun 2020; 11(1): 1620

25. World Health Organization. Tobacco fact sheet. 2020. http://www. who.int/mediacentre/factsheets/fs339/en/ (accessed December 8, 2020)

26. Carter BD, Abnet CC, Feskanich D, Freedman ND, Hartge P, Lewis CE, Ockene JK, Prentice RL, Speizer FE, Thun MJ, Jacobs EJ. Smoking and mortality - beyond established causes. N Engl J Med 2015; 372(7): 631-640

27. Centers for Disease Control and Prevention (US), National Center for Chronic Disease Prevention and Health Promotion (US), Office on Smoking and Health (US). How tobacco smoke causes disease: the biology and behavioral basis for smoking-attributable disease: a report of the surgeon general. Atlanta (GA): Centers for Disease Control and Prevention (US). 2010. http://www.ncbi.nlm.nih.gov/ books/NBK53017/ (accessed December 8, 2020)

28. Zhou G. Tobacco, air pollution, environmental carcinogenesis, and thoughts on conquering strategies of lung cancer. Cancer Biol Med 2019; 16(4): 700-713

29. Liu J, Peng Y, Zhang J, Long J, Liu J, Wei W. Targeting SCF E3 ligases for cancer therapies. Adv Exp Med Biol 2020; 1217: 123146

30. Xu JY, Zhang C, Wang X, Zhai L, Ma Y, Mao Y, Qian K, Sun C, Liu Z, Jiang S, Wang M, Feng L, Zhao L, Liu P, Wang B, Zhao X, Xie H, Yang X, Zhao L, Chang Y, Jia J, Wang X, Zhang Y, Wang Y, Yang Y, Wu Z, Yang L, Liu B, Zhao T, Ren S, Sun A, Zhao Y, Ying W, Wang F, Wang G, Zhang Y, Cheng S, Qin J, Qian X, Wang Y, Li J, He F, Xiao T, Tan M. Integrative proteomic characterization of human lung adenocarcinoma. Cell 2020; 182(1): 245-261.e17

31. Deshotels MR, Xia H, Sriramula S, Lazartigues E, Filipeanu CM. Angiotensin II mediates angiotensin converting enzyme type 2 internalization and degradation through an angiotensin II type I receptor-dependent mechanism. Hypertension 2014; 64(6): 13681375 